\section{Challenges and pitfalls in the diagnosis of hyperprolactinemia}

\author{
Desafios e armadilhas no diagnóstico da hiperprolactinemia
}

Lucio Vilar1, Maria Fleseriu², Marcello D. Bronstein ${ }^{3}$
${ }^{1}$ Division of Endocrinology, Hospital das Clínicas, Universidade Federal de Pernambuco (UFPE), Recife, PE, Brazil ${ }^{2}$ Departments of Medicine and Neurological Surgery, and Northwest Pituitary Center, Oregon Health \& Science University, Portland, OR, USA ${ }^{3}$ Neuroendocrine Unit, Division of Endocrinology and Metabolism, Hospital das Clínicas, Universidade de São Paulo (USP), São Paulo, SP, Brazil challenge is macroprolactinemia, a common finding that needs to be identified, as it usually requires no treatment. Although most macroprolactinemic patients are asymptomatic, many of them may present galactorrhea or menstrual disorders, as well as neuroradiological abnormalities, due to the concomitance of other diseases. Finally, physicians should be aware that pituitary incidentalomas are found in at least $10 \%$ of adult population. Arq Bras Endocrinol Metab. 2014;58(1):9-22

\title{
Keywords
}

Hyperprolactinemia; diagnostic pitfalls; hook effect; macroprolactinemia; pituitary incidentalomas

\section{RESUMO}

A definição da etiologia da hiperprolactinemia muitas vezes representa um grande desafio e um diagnóstico preciso é fundamental antes do tratamento. Embora níveis de prolactina $>200-250 \mathrm{ng} / \mathrm{mL}$ sejam altamente sugestivos de prolactinomas, ocasionalmente podem ser encontrados em outras condições. Além disso, até $25 \%$ dos pacientes com microprolactinomas podem apresentar-se com níveis de prolactina $<100 \mathrm{ng} / \mathrm{mL}$, os quais são evidenciados na maioria dos pacientes com pseudoprolactinomas, hiperprolactinemia induzida por drogas ou doenças sistêmicas. Por outro lado, deve-se atentar às condições que podem levar a valores de prolactina falsamente baixos, particularmente o chamado efeito gancho. Este último é um artefato causado por um nível extremamente elevado de PRL e que pode ser confirmado pela repetição do exame após diluição do soro a 1:100. 0 efeito gancho deve ser considerado em todo paciente com grandes adenomas hipofisários e níveis de prolactina dentro da faixa normal ou apenas moderadamente elevados (p. ex., $<200 \mathrm{ng} / \mathrm{mL}$ ). Um efeito gancho não detectado pode levar a diagnóstico incorreto e intervenção cirúrgica desnecessária em pacientes com prolactinomas. Outro desafio importante é a macroprolactinemia, um achado comum que precisa ser identificado visto que geralmente não requer tratamento. Ainda que a maioria dos pacientes seja assintomática devido à concomitância de outras doenças, muitos podem apresentar galactorreia ou distúrbios menstruais, bem como anormalidades neurorradiológicas. Finalmente, os médicos devem estar cientes de que incidentalomas hipofisários são encontrados em pelo menos 10\% da população adulta. Arq Bras Endocrinol Metab. 2014;58(1):9-22

\section{Descritores}

Hiperprolactinemia; armadilhas diagnósticas; efeito gancho; macroprolactinemia; incidentalomas hipofisários

\section{INTRODUCTION}

$\mathrm{H}$ yperprolactinemia is the most common endocrine disorder of the hypothalamic-pituitary axis (1-3).
The elevation of prolactin (PRL) serum levels is not an unique disease per se. Rather, it has multiple etiologies $(4,5)$. A prolactinoma is the most common cause of 
chronic hyperprolactinemia after pregnancy, primary hypothyroidism, and drugs that rise serum prolactin levels have been ruled out (6).

The occurrence of clinically apparent hyperprolactinemia depends on the study population (7). The prevalence has been reported to range from $0.4 \%$ in an unselected healthy adult population in Japan to $5 \%$ seen at a family planning clinic (8). The rate is even higher among patients with specific symptoms possibly related to hyperprolactinemia. Indeed, it is estimated at $9 \%$ among women with amenorrhea, $25 \%$ among women with galactorrhea, 16-30\% among women with infertility, and as high as $70 \%$ among women with both amenorrhea and galactorrhea (7-9). Hyperprolactinemia has also been reported to be present in 3-10\% of patients with erectile dysfunction and/or premature ejaculation (10).

The measurement of PRL levels has increasingly broader indications. It is included in the work-up for menstrual disorders, infertility and galactorrhea in women, and in the work-up for sexual dysfunction or infertility in men. Moreover, it plays a fundamental role in the evaluation and monitoring of sellar tumors $(4,5)$.

When determining the etiology of hyperprolactinemia and interpreting PRL levels, clinicians need to be aware of some conditions that can lead to misdiagnosis and, consequently, to inappropriate management. In this review article, the authors aim to comment on the most important causes of hyperprolactinemia and particularly to emphasize the main challenges and pitfalls that can be faced in the diagnostic approach of hyperprolactinemic subjects.

\section{PROLACTIN FUNCTION AND REGULATION}

Prolactin primary function in humans is to assist in the development and maturation of the breast during pregnancy and the subsequent production of milk during lactation. Unlike the other hormones of the adenohypophysis, prolactin secretion is predominantly under inhibitory effect of the hypothalamus by means of one or more PRL inhibitory factors (PIF) that reach the pituitary via the hypothalamic-pituitary portal vessels $(3,5,11)$. Dopamine is the main physiological PIF, which acts on surface membrane of dopamine $\mathrm{D}_{2}$ receptors on lactotroph cells. Disruption of the pituitary stalk and, therefore, the transport of dopamine to the lactotrophs, or blockade of endogenous dopamine receptors by a variety of drugs, leads to a moderate increase in PRL secretion $(7,11,12)$. There are a number of agents that also stimulate PRL synthesis and release, including thyrotropin releasing hormone (TRH), vasoactive intestinal peptide (VIP), oxytocin, and estrogen (4-6).

\section{PROLACTIN SERUM ISOFORMS}

PRL size is heterogeneous in terms of circulating molecular forms. The predominant form in healthy subjects and in patients with prolactinomas is monomeric PRL (molecular mass $23 \mathrm{kDa}$ ), while dimeric or big PRL (45$60 \mathrm{kDa}$ ), and big-big PRL or macroprolactin (150-170 $\mathrm{kDa}$ ) correspond to less than $20 \%$ of the total PRL (13$15)$. When the serum of a patient with hyperprolactinemia contains mostly macroprolactin, the condition is termed macroprolactinemia $(16,17)$. In approximately $90 \%$ of cases, macroprolactin is composed of a complex formed by an IgG and a monomeric PRL $(17,18)$. Macroprolactin causes hyperprolactinemia as a consequence of low renal PRL clearance and decreased stimulation of the dopaminergic tonus (19). Though still controversial, studies indicate that macroprolactin has both low bioactivity and bioavailability $(17,19,20)$, thus explaining why most patients with macroprolactinemia lack typical symptoms related to hyperprolactinemia $(17,19,21)$.

\section{ETIOLOGY}

Causes of hyperprolactinemia fall into three main categories: physiologic, pharmacologic and pathologic. Furthermore, as previously mentioned, hyperprolactinemia can arise when macroprolactin is the predominant isoform $(19,21)$ (Tables 1 and 2).

\section{PHYSIOLOGIC CAUSES}

The most important physiologic causes of hiperprolactinemia are pregnancy and breast-feeding $(3,4)$. During normal pregnancy, serum PRL progressively rises to around 200 to $500 \mathrm{ng} / \mathrm{mL}(4,000$ to $10,000 \mathrm{mU} / \mathrm{L})$, an increase thought to be due to rising estrogen concentrations (11).

A variety of stress conditions (e.g., physical discomfort, exercise, hypoglycemia, myocardial infarction, surgery, fear of venipuncture, etc.), food ingestion, coitus, and sleep, are also potent stimuli to PRL release $(3,11)$. Psychological stress may cause minimal elevations of PRL (22), but chronic hyperprolactinemia has not been reported with any chronic psychiatric state except pseudocyesis, in which PRL levels fall with psychotherapy $(22,23)$. 
Table 1. Causes of hyperprolactinemia

Physiologic
Pregnancy; lactation; stress; sleep; coitus; exercise

\section{Pathologic}

Systemic diseases - Primary hypothyroidism; adrenal insufficiency; PCOS (?); renal insufficiency; cirrhosis; pseudocyesis; epileptic seizures

Hypothalamic diseases - tumors (craniopharyngiomas, dysgerminomas, meningiomas, etc.); infiltrative disorders (histiocytosis, sarcoidosis, etc.), metastasis; cranial radiation; Rathke's cleft cysts, etc.

Pituitary diseases - Prolactinomas; acromegaly; thyrotropinomas; Cushing's disease; infiltrative disorders; metastasis; lymphocytic hypophysitis; empty sella syndrome, etc.

Stalk disorders - Hastitis; seccion; traumatic brain injury (TBI)

Neurogenic - Chest wall lesions (burns; breast surgery; thoracotomy; nipple rings; herpes zoster; etc.); spinal cord injury (cervical ependymoma; tabes dorsalis; extrinsic tumors; etc.), breast stimulation, etc.

Idiopathic

Ectopic prolactin production - Renal cell carcinoma; ovarian teratomas; gonadoblastoma; non-Hodgkin lymphoma, uterine cervical carcinoma; colorectal adenocarcinoma, etc.)

Macroprolactinemia

Drug-induced (Table 2)

Table 2. Drug-induced hyperprolactinemia

\begin{tabular}{l}
\hline Antipsychotics \\
Typical - Phenothiazines; butirophenones; thyoxanthe \\
Atypical - Risperidone; molindone; amisulpride; quetiapir \\
Antidepressants \\
Tricyclics - Amitriptyline; desipramine; clomipramine \\
MAO inhibitors - Pargyline; clorgyline \\
SSRIs - Fluoxetine; citalopram; paroxetine
\end{tabular}

\section{Antihypertensive drugs}

Verapamil; $\alpha$-methyldopa; reserpine; labetolol

\section{Anticonvulsivants}

Phenytoin

\section{Prokinetic agents}

Metoclopramide; domperidone

Others

Estrogens; anesthetics; cimetidine; ranitidine; opiates; methadone; morphine; apomorphine; heroin; cocaine; marijuana; alcohol; sibutramine, etc.

\section{PHARMACOLOGIC CAUSES}

The most common cause of non-physiological hyperprolactinemia is the use of drugs that act through different mechanisms: increased transcription of PRL gene (estrogens), antagonism of dopamine receptor (risperidone, haloperidol, metoclopramide, domperidone, sulpiride, etc.), dopamine depletion (reserpine, methyldopa), inhibition of hypothalamic dopamine production (verapamil, heroin, morphine, enkephalin analogs, etc.), inhibition of dopamine reuptake (tricyclic antidepressants, cocaine, amphetamine, monoamine oxidase inbibitors), inhibition of serotonin reuptake (opiates, fenfluramine, fluoxetine, sibutramine), etc. (1,4-7,22,24-26). Any drug that affects the hypothalamic dopamine system and/or pituitary dopamine receptors can potentially induce hyperprolactinemia $(6,26)$.

Vilar and cols. (27) showed in the Brazilian Multicenter Study on Hyperprolactinemia (BMSH), that antidepressants and neuroleptics (in monotherapy or in combination) were the culprit in a large majority of the cases $(82.2 \%)$. Among antipsychotics, the most frequently involved ones were haloperidol, phenothiazines, and risperidone, while tricyclic drugs are the main representants among the antidepressants. Other studies (28) found the following rates of hyperprolactinaemia associated with each therapeutic drug class: $31 \%$ for neuroleptics, $28 \%$ for neurolepticlike drugs, 26\% for antidepressants, $5 \%$ for $\mathrm{H} 2$-receptor antagonists, and $10 \%$ for other drugs.

In one group of 106 patients receiving antipsychotics, hyperprolactinemia was present in $81 \%, 35 \%, 29 \%$, and $38 \%$ of patients taking risperidone, olanzapine, ziprasidone, and typical antipsychotics, respectively (29).

The newer atypical antipsychotics (AAP) are characterized by increased antipsychotic efficacy, and fewer neurological and endocrine related side-effects as compared to classical antipsychotic drugs. With the exception of risperidone, amilsulpride and molindone that are often associated with high PRL levels (30), most of AAP elicit poor hyperprolactinemic response or no hyperprolactinemia at all (12). Furthermore, addition of drugs like quetiapine and aripiprazole was shown to reverse the hyperprolactinemia induced by other AAPs (31).

The evaluation of drug-induced hyperprolactinemia can be challenging; it is noteworthy to always consider the concomitance of a pathologic cause. In an ideal situation (if it is possible with the disease, and corroborated by a psychiatrist, it is recommended to perform repeated PRL measurements after discontinuing the medication for at least 3 to 4 days. When drug withdrawal is unsafe, an MRI should be performed to rule out a sellar mass. If drug-induced hyperprolactinemia is confirmed, one should try to switch to an alternative medication $(6,19)$.

One of our patients chronically treated with haloperidol presented moderate increase in PRL levels $(60-95 \mathrm{ng} / \mathrm{mL})$ which was attributed to the drug. When she developped amenorrhea three years later, a pituitary MRI was performed, disclosing a huge sellar mass, 
confirmed to be a non-functioning pituitary adenoma (Figure 1). Therefore, the presence of an apparent druginduced hyperprolactinemia does not necessarily exclude other disorders and/or the need for a pituitary MRI.

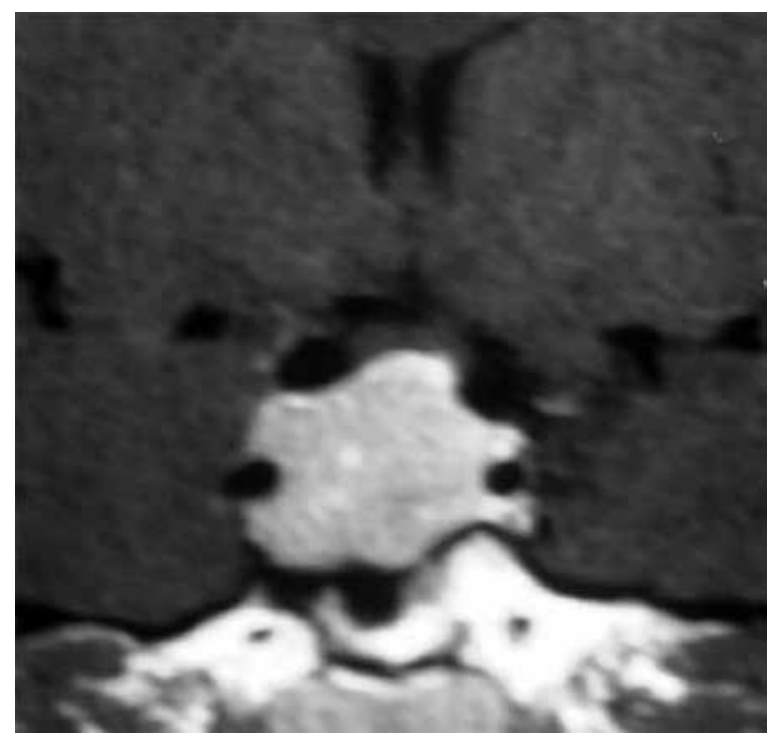

Figure 1. Huge sellar mass (confirmed to be a non-functioning pituitary adenoma) in a patient chronically treated with haloperidol who presented with mild elevation of prolactin.

\section{PATHOLOGIC CAUSES}

\section{Pituitary and hypothalamic disordes}

Prolactin secreting pituitary adenomas or prolactinomas represent the most common type of pituitary adenoma (about $40 \%$ ) being the main cause of pathological hyperprolactinemia (4-6). Other tumors of the hypothalmic-pituitary region may also present hyperprolactinemia, either by increased production of PRL (mixed pituitary adenomas producing GH and PRL, TSH and PRL, or ACTH and PRL) or by compression of the pituitary stalk (e.g., clinically non-functioning pituitary adenomas and craniopharyngiomas) $(4,5)$. In the latter situation, such tumors are called pseudoprolactinomas since they do not secrete PRL, but rather interfere with the supply of dopamine from the hypothalamus to the pituitary (3-5). Infiltrating lesions, hypophysitis, aneurisms, empty sella, and radiotherapy can also result in hyperprolactinemia due to inadequate hypothalamic production of dopamine or to pituitary stalk disruption $(3,22)$. Interestingly, hypophysitis can also present very low prolactin levels (32).

\section{Systemic diseases}

Pathological hyperprolactinemia can be also caused by other endocrine and non-endocrine systemic diseases. Up to $40 \%$ percent of patients with overt primary hypothyroidism, and up to $22 \%$ of those with subclinical hypothyroidism (defined by increased TSH with normal serum thyroid hormones) could have mild elevation of PRL levels that can be normalized by thyroid hormone replacement $(3,33,34)$. The major mechanism causing hyperprolactinemia in primary hypothyroidism is an increase in TRH levels, which in turn stimulates PRL secretion. Moreover, other mechanisms, such as reduced PRL clearance, decreased sensitivity to the suppressant effect of dopamine on PRL synthesis, and decreased circulating thyroid hormone levels could also be involved $(5,19)$. Furthermore, one should be aware of the occasional concomitance of primary hypothyroidism and prolactinomas. Although rare, it should be kept in mind when high PRL levels persist despite normalization of thyroid function (Figure 2) (1,4). Glucocorticoids have a suppressible effect on PRL gene expression and PRL release (22). Thus, hyperprolactinemia may occasionally be observed in patients with adrenal insuficiency in whom PRL levels return to normal with glucocorticoid replacement $(3,22,35)$.

The relationship between polycystic ovary syndrome (PCOS) and hyperprolactinemia remains controversial. Several studies showed a high rate (up to $30 \%$ ) of hyperprolactinemia in women with PCOS, thought to be a consequence of elevated estrogen levels and dopaminergic tonus reduction $(19,36)$. However, a physiopathological link between PRL and PCOS was not confirmed in two recent studies, and their relationship was considered a fortuitous association $(37,38)$.

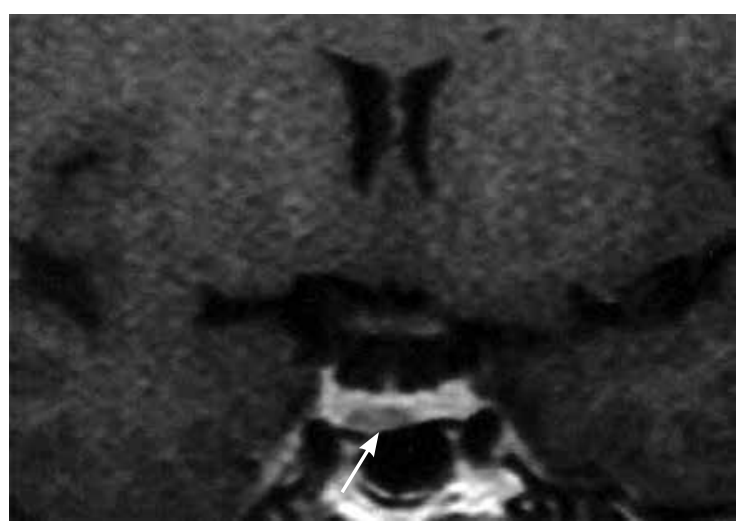

Figure 2. Microprolactinoma in a patient with primary hypothyroidism (arrow). This condition should be considered whenever PRL levels remain elevated following normalization of TSH and free $\mathrm{T}_{4}$. 
About $30 \%$ of patients with chronic renal failure, and up to $80 \%$ of patients on hemodialysis have elevated PRL levels. This is probably secondary to decreased clearance and increased production of PRL as a result of disordered hypothalamic regulation of PRL secretion. Correction of renal failure by transplantation results in normoprolactinemia, sometimes within days $(3,11,39)$. Mild hyperprolactinemia is also found, with variable frequencies, in alcoholic cirrhosis (16 to $100 \%$ ) and nonalcoholic cirrhosis (5 to $13 \%)(22,40)$. The etiopathogenesis in these cases is unknown $(19,41)$.

\section{Idiopathic hyperprolactinemia}

The term idiopathic hyperprolactinemia (IH) has been reserved for patients without an obvious cause for the disorder $(5,22)$. Presumably, in many such cases, small prolactinomas may be present but are too small (e.g., < $3 \mathrm{~mm}$ ) to be detected by current radiological techniques. In other cases, PRL elevation could result from hypothalamic regulatory dysfunction (6). In one-third of the patients with $\mathrm{IH}$, elevated PRL levels will resolve, and in one-half of patients, PRL levesl will remain stable $(1,3)$. Alternatively, De Bellis and cols. (42) found high prevalence of anti-pituitary antibodies (APA) in $25.7 \%$ of patients with idiopathic hyperprolactinemia, whereas all patients with microprolactinomas and normal controls were negative for APA. It is noteworthy that many cases initially diagnosed as IH were later confirmed as having macroprolactinemia (43-45).

\section{Neurogenic hyperprolactinemia}

Sexual breast stimulation and breastfeeding lead to reflex release of PRL, in part, by afferent neural pathways going through spinal cord. The same mechanism would explain elevation of PRL levels following traumatic or irritative lesions, disorders of the chest wall (mastectomy and thoracotomy, herpes zoster, burns, etc.), of the spinal cord (cervical ependymoma, syringomyelia, tabes dorsalis, extrinsic tumors), and nipple rings $(3,5,22)$. The association of hyperprolactinemia with chronic nipple piercing was reported by some authors $(46,47)$, but not confirmed in a recent study (48).

\section{Ectopic prolactin secretion}

An unusual and extremely rare cause of hyperprolactinemia is the ectopic production of PRL. Symptomatic hyperprolactinemia due to well-documented PRL production from renal cell carcinoma (49), gonadoblasto- ma (50), uterine cervical carcinoma (51), non-Hodgkin lymphoma (52), colorectal adenocarcinoma (53), and ectopic pituitary tissue in three ovarian teratomas (5456) has been reported. More recently, probable PRL ectopic secretion by a perivascular epithelioid cell tumor (57) and a low grade malignant mesenchymal tumor (58) were reported, but staining for PRL in the tumors was negative.

Given its rarity, the search for an ectopic source of PRL secretion is not warranted unless there is a great clinical evidence of an extrapituitary tumor $(3,22)$.

\section{Macroprolactinemia}

Macroprolactinemia is a condition where more of $60 \%$ of circulating PRL is made up of macroprolactin (44). It may be observed in both sexes (although women represent about $90 \%$ of published cases), and at all ages, including subjects over 65 y.o. and below 12 y.o. $(1,59)$. In recent studies, its prevalence has ranged between $10-26 \%(44,59-61)$, but the precise prevalence of macroprolactinemia in hyperprolactinemic populations remains largely unknown.

Different assays recognize macroprolactin differently (62). It has been demonstrated that some of the new assays show lower cross-reactivity with macroprolactin; however, the number of samples defined as macroprolactin is still significant (63).

Pituitary PRL is antigenic, leading to the production of anti-PRL auto-antibodies. These antibodies reduce PRL bioactivity and delay its clearance, inducing macroprolactinemia. Antibody-bound PRL is big enough to be confined to vascular spaces and, therefore, macroprolactinemia seems to develop mostly due to the delayed PRL clearance, rather than its increased production $(16,17)$.

\section{Methods for detection of macroprolactin}

The gold standard for the diagnosis of macroprolactinemia is gel-filtration chromatography, but because this method is laborious and expensive, polyethylene glycol (PEG) serum precipitation has been widely used as a screening method $(16,17,44,45,61,63)$. The test, which enables the diagnosis in at least $80 \%$ of cases, is based on the observation that immunoglobulins exposure to defined concentrations of PEG lead to their insolubilization $(1,4,63)$. PEG precipitates macroprolactin, whose levels in the supernatant decrease significantly. Recoveries $<40 \%$ are indicative 
of predominance of macroprolactin whereas recoveries $>60 \%$ point to the diagnosis of monomeric hyperprolactinemia $(44,63,64)$.

\section{Clinical relevance}

As previously mentioned, macroprolactinemia is a common finding in endocrinological practice that usually requires no treatment. It has been mostly suspected when hyperprolactinemic patients do not present the typical symptoms and/or evidence of a pituitary tumor on magnetic resonance imaging (MRI) $(15,21,44,60,65,66)$. However, many patients with macroprolactinemia can have nonspecific symptoms, and neuroradiological abnormalities are also frequent (see below) $(44,59,65)$. Furthermore, PRL levels are highly variable and overlap with those found in patients with monomeric hyperprolactinemia $(44,59,61,65)$. So, neither of these conditions can be differentiated on the basis of clinical features, MRI findings or PRL levels alone.

One should also bear in mind that macroprolactinemia may be associated with any other causes of hyperprolactinemia $(4,19,59,60)$. In this context, macroprolactinemia association with pituitary adenomas requires special attention $(67,68)$, especially if PRL levels remain elevated after PEG precipitation (Figure 3 ) $(1,4,65)$. However, the prevalence of macroprolactinemia did not differ in patients with prolactinomas and in the control group $(3.5 \%$ vs. $3.7 \% ; \mathrm{p}=1.00)$ in a recent study (69). Macroprolactinemia was recently reported in $5.8 \%$ of women with PCOS (70).

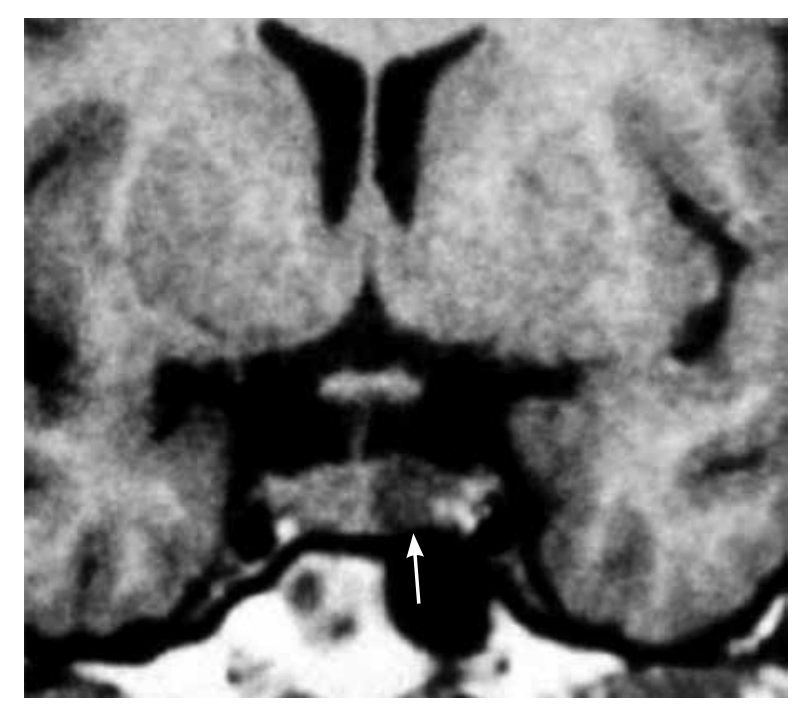

Figure 3. Microprolactinoma in a patient with macroprolactinemia (arrow). After PEG precipitation, PRL recovery was low (25\%) but PRL levels remained elevated $(93 \mathrm{ng} / \mathrm{mL})$.
Unfortunately, sometimes, the presence of macroprolactinemia may delay or hamper the diagnosis of psychogenic erectile dysfunction (71). This situation should be considered whenever patients with erectile dysfunction and hyperprolactinemia have normal testosterone levels.

In conclusion, presence of macroprolactin may change the initial diagnosis in a large proportion of patients. In the series reported by Isik and cols. (44), idiopathic hyperprolactinemia, was initially diagnosed in 41 patients, and was subsequently excluded in 28 of them (63\%). Moreover, diagnosis of PRL-secreting pituitary microadenoma shifted to non-secreting pituitary microadenoma in 10 of 49 patients $(20 \%)$ (44). Thus, macroprolactinaemia may represent a relevant cause of misdiagnosis, unnecessary investigation and inappropriate treatment.

\section{DIAGNOSTIC EVALUATION}

For the correct identification of the etiology of hyperprolactinemia, some parameters must be taken into account: medical history, physical examination, clinical features, laboratory findings (especially PRL serum levels), as well as imaging studies of the pituitary and sella turcica. Furthermore, the screening for macroprolactinemia should often be considered.

In addition to PRL determination, $\mathrm{TSH}$, free $\mathrm{T}_{4}$, and creatinine levels should be obtained to rule out secondary causes of hyperprolactinemia $(1,4,39)$. Moreover, acromegaly must be investigated by means of IGF-1 measurement in all patients with a macroadenomas, even though there are no manifestations of this disease (72). Finally, $\beta$-hCG measurement is mandatory in any childbearing woman with amenorrhea $(1,4)$.

\section{Medical history and physical examination}

Once hyperprolactinemia is detected, one should first investigate the use of substances that may rise PRL levels. It is mandatory to rule out pregnancy in amenorrheic women with hyperprolactinemia, even though they sometimes categorically deny such a possibility. There have been cases of pregnant woman who inadvertently underwent a pituitary CT scan in the investigation of hyperprolactinemia. It is important to remember, that opiate abuse and the use of some illicit drugs (e.g., cocaine and marijuana), are also possible causes of hyperprolactinemia (73), and this information may be omitted by patients during history taking. 
Data that could reinforce primary hypothyroidism is the presence of goiter or a surgical scar in the anterior cervical region, prior head or neck radiotherapy, the presence of menorrhagia - observed in about one third of the cases (74) - or the presence of typical manifestations of thyroid dysfunction (cold intolerance, slurred speech, drowsiness, asthenia, etc.). It should be emphasized, however, that many hypothyroid patients are asymptomatic (74), and that hyperprolactinemia may also be found in patients with subclinical hypothyroidism (33). So, the possibility of primary hypothyroidism should also always be considered regardless the presence of symptoms suggestive of the disease.

Although galactorrhea is the most characteristic clinical manifestation of hyperprolactinemia, it is not always present and may be intermittent or only detectable by the expression in the nipple (75). Indeed, among patients with prolactinomas, galactorrhea has been reported in $30-80 \%$ of women and $14-33 \%$ of men $(5,75)$. Moreover, up to $50 \%$ of women with galactorrhea have normal PRL levels, characterizing the so-called idiopathic galactorrhea (76). On physical examination, one must also investigate the presence of irritative or traumatic lesions of chest wall (e.g., burns, herpes zoster, recent surgical scars, nipple rings, etc.) which could cause reflex PRL elevation $(1,4,5,22)$. It is advisable to perform the breast exam apart from drawing PRL to prevent false elevation.

\section{Other clinical features}

As already mentioned, the typical manifestations of hyperprolactinemia are galactorrhea and symptoms associated with hypogonadism: oligomenorrhea, amenorrhea, infertility, decreased libido, and erectile dysfunction. Prolonged hypogonadism in both women and men may result in increased bone loss. Moreover, neuro-ophthalmogical symptoms can be observed in patients with macroprolactinomas. Few patients with prolactinomas are asymptomatic $(5,27,39)$. When typical symptoms of hyperprolactinemia are absent, macroprolactinemia should be suspected $(6,7)$. However, the presence of galactorrhea, menstrual disorders and/ or infertility does not exclude this diagnosis. Indeed, one or more of these manifestations have been described in at least $30 \%$ of cases. In a large series, galactorrhea, menstrual disorders, infertility and association of galactorrhea and menstrual disorders were found in $46 \%, 39 \%, 28 \%, 28 \%$ and $12 \%$ respectively, presu- mably resulting from concomitant disorders, such as PCOS, pituitary tumors, etc. (59). Their overall prevalence was somewhat lower than those observed in patients with monomeric hiperprolactinemia (Table 3 ). Similar data has been reported in subsequent studies $(16,17,21,45,60,65)$ (Table 3) (Figure 4). Asymptomatic patients are more numerous in the macroprolactinemic group $(44,65)$.

Pituitary adenomas are rarely associated with diabetes insipidus (DI) (77). Thus, when a hyperprolactinemic patient present with a sellar mass and DI, a pituitary adenoma is less likely; differential diagnosis should include other types of sellar tumors (e.g., dysgerminoma, craniopharyngioma, etc.), hypophysitis, metastasis or other infiltrative disorders $(77,78)$.

\section{Imaging studies}

Computed tomography (CT) scanning and especially magnetic resonance imaging (MRI) virtually visualize all macroprolactinomas (diameter $\geq 10 \mathrm{~mm}$ ) and pseudoprolactinomas, as well as most microprolactinomas (diameter $<10 \mathrm{~mm})(77,79)$. On the other hand, at least $10 \%$ of the general adult population undergoing dedicated imaging have a possible pituitary microadeno$\mathrm{ma}(80,81)$. Thus, the lesion seen on the MRI may be an incidental finding in patients whose hyperprolactinemia has other etiologies: drug-induced systemic disease, or macroprolactin predominance $(44,59,61,65,68)$. Furthermore, primary hypothyroidism may result in pituitary hyperplasia and diffuse pituitary enlargement that could lead to misdiagnosis of prolactinoma or pseudoprolactinoma. Indeed, there have been reports of patients who unduly underwent pituitary surgery. Pituitary enlargement is reversible with L-thyroxine replacement $(82,83)$ (Figure 5).

Abnormal pituitary images (microadenomas, cystic lesions, empty sella or, less frequently, macroadenomas) have been reported in $8-26 \%$ of patients with macroprolactinemia $(21,43,44,59,65)$ but this frequency is similar to that found in the general population (6$20 \%)(80,81)$. However, in a recent study involving 88 macroprolactinemic patients, $65 \%$ had abnormal MRI, compared with $81 \%$ of 244 subjects with monomeric hyperprolactinemia (44). Other authors have highlighted that macroprolactinemia and pituitary incidentalomas could coexist $(19,68)$, a situation in which one can mistakenly attribute hyperprolactinemia to a microprolactinoma. 
Table 3. Comparison of clinical, biological, and neuroradiological findings between macroprolactinemic patients and subjects with monomeric hyperprolactinemia from 3 series

\begin{tabular}{|c|c|c|c|}
\hline Findings & Macroprolactinemia & Monomeric hyperprolactinemic & $\mathrm{p}$-value \\
\hline \multicolumn{4}{|l|}{ Females } \\
\hline Vallette-Kasic and cols. (59) & $94 \%$ & $N A^{*}$ & - \\
\hline Vilar and cols. (65) & $85 \%$ & $83 \%$ & ns \\
\hline Isik and cols. (44) & $90 \%$ & $95.5 \%$ & ns \\
\hline \multicolumn{4}{|l|}{ Mean age (years) } \\
\hline Vallette-Kasic and cols. (59) & $35.0 \pm 11.1$ & $32.8 \pm 9.5$ & ns \\
\hline Vilar and cols. (65) & $38.0 \pm 12.1$ & $36.4 \pm 10.5$ & ns \\
\hline Isik and cols. (44) & $30.7 \pm 9.8$ & $35.0 \pm 10.1$ & 0.0161 \\
\hline \multicolumn{4}{|l|}{ Mean PRL levels (ng/mL) } \\
\hline Vallette-Kasic and cols. (59) & $35.0 \pm 11.1$ & $32.8 \pm 9.5$ & ns \\
\hline Vilar and cols. (65) & $113.3 \pm 94.5$ & $565.9 \pm 2726.4^{\star \star}$ & $<0.001$ \\
\hline Isik and cols. (44) & $95.6 \pm 47.3$ & $125.3 \pm 123.9$ & ns \\
\hline \multicolumn{4}{|l|}{ Only galactorrhea } \\
\hline Vallette-Kasic and cols. (59) & $46 \%$ & $66 \%$ & 0.003 \\
\hline Vilar and cols. (65) & $13 \%$ & $29 \%$ & ns \\
\hline Isik and cols. (44) & $39 \%$ & $57 \%$ & 0.04 \\
\hline \multicolumn{4}{|l|}{ Only menstrual disorders } \\
\hline Vallette-Kasic and cols. (59) & $39 \%$ & $49 \%$ & 0.04 \\
\hline Vilar and cols. (65) & $24 \%$ & $26 \%$ & ns \\
\hline Isik and cols. (44) & $36 \%$ & $54 \%$ & ns \\
\hline \multicolumn{4}{|c|}{ Galactorrhea + menstrual disorders } \\
\hline Vallette-Kasic and cols. (59) & $12 \%$ & $34 \%$ & 0.003 \\
\hline Vilar and cols. (65) & $2 \%$ & $34 \%$ & $<0.0001$ \\
\hline Isik and cols. (44) & NA & NA & - \\
\hline \multicolumn{4}{|l|}{ Erectile dysfunction } \\
\hline Vallette-Kasic and cols. (59) & $50 \%$ & NA & - \\
\hline Vilar and cols. (65) & 50 & 42 & ns \\
\hline Isik and cols. (44) & $50 \%$ & $72 \%$ & ns \\
\hline \multicolumn{4}{|l|}{ No symptoms } \\
\hline Vallette-Kasic and cols. (59) & NA & NA & - \\
\hline Vilar and cols. (65) & $61 \%$ & $11 \%$ & $<0.0001$ \\
\hline Isik and cols. (44) & $32 \%$ & $11 \%$ & 0.02 \\
\hline \multicolumn{4}{|l|}{ Normal MRI } \\
\hline Vallette-Kasic and cols. (59) & $78 \%$ & $69 \%$ & ns \\
\hline Vilar and cols. (65) & $24 \%$ & $80 \%$ & $<0.0001$ \\
\hline Isik and cols. (44) & $34 \%$ & $18 \%$ & 0.02 \\
\hline
\end{tabular}

${ }^{*}$ Sex ratio (female/male) of $87 / 1 ;{ }^{* *} 119.5 \pm 64.9 \mathrm{ng} / \mathrm{mL}$ without including macroprolactinomas ( $\mathrm{p}=0.842$ vs. macroprolactinemia).

NA: not available.

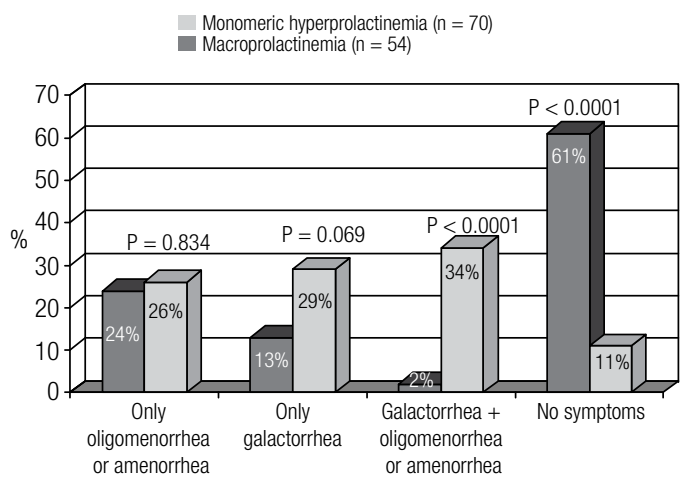

Figure 4. Comparative clinical features in women with macroprolactinemia or monomeric hyperprolactinemia (Adapted from Ref. 65).
Detection of macroprolactinemia does not necessarily exclude the need to perform imaging studies of the sellar region, particularly if there are symptoms associated with hyperprolactinemia or neuro-ophthalmologic manifestations. The following case is illustrative: a young overweight woman with oligomenorrhea attributed to PCOS and macroprolactinemia was prescribed an oral contraceptive agent. Four months later, she presented intense headache and a subsequent pituitary MRI demonstrated a large macroadenoma (Figure 6). 


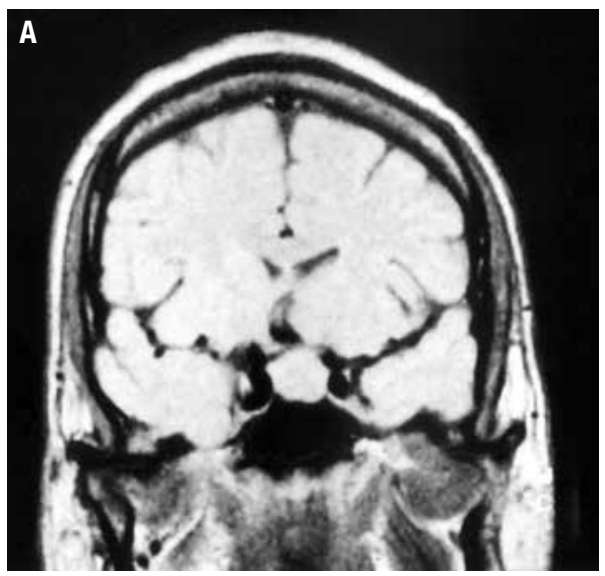

Baseline

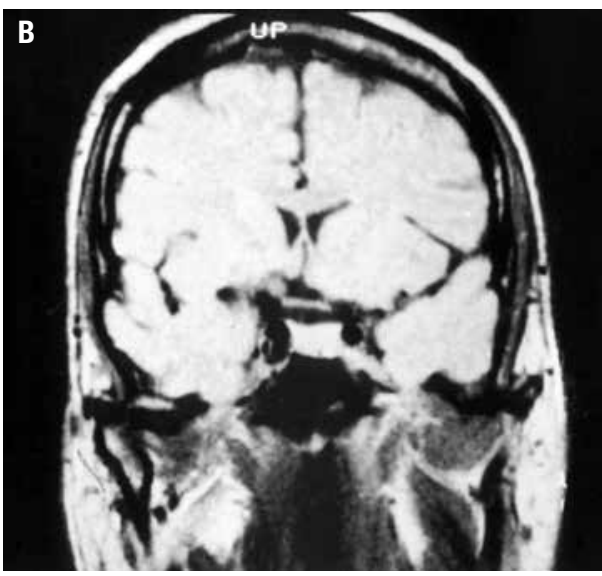

After 6 months of L-thyroxine replacement

Figure 5. Diffuse pituitary enlargement in a patient with primary hypothyroidism-induced hyperprolactinemia, before $(\mathbf{A})$ and after $(\mathbf{B})$ L-thyroxine replacement.
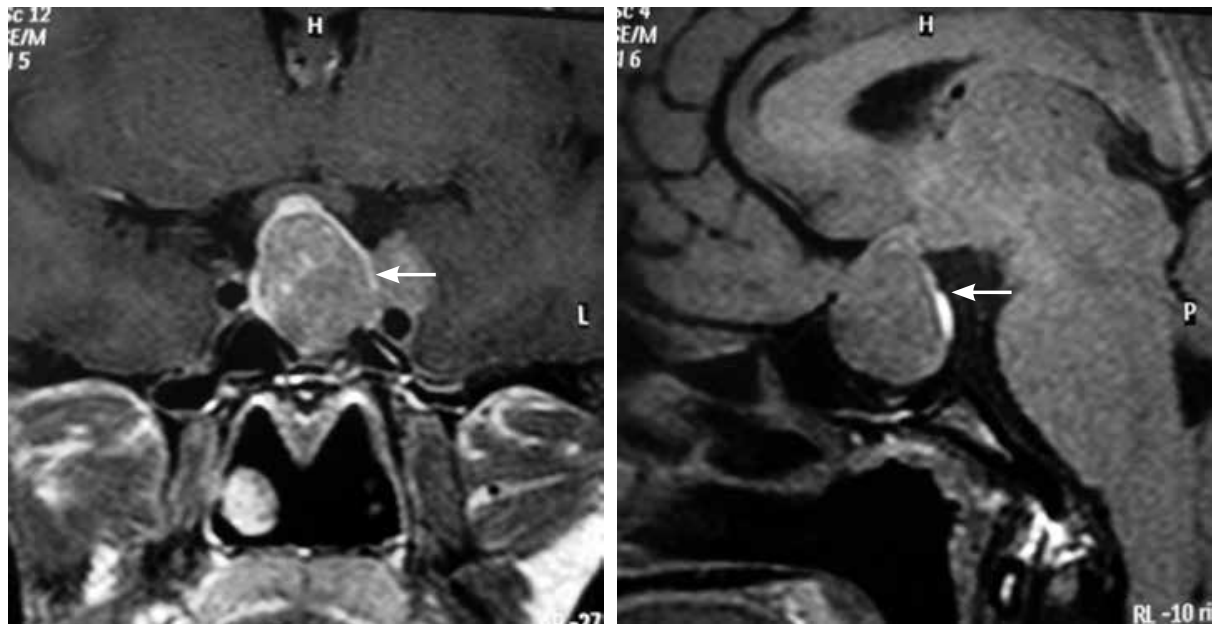

Figure 6. Large non-functioning pituitary adenoma disclosed in a patient with macroprolactinemia (arrows).

\section{Prolactin levels}

Vigorous exercise and nipple stimulation should be avoided for at least 30 minutes before checking PRL levels (39). However, supine rest is not necessary prior to sampling. Venipuncture stress may cause elevation in PRL level, but it is usually mild $(<40$ $60 \mathrm{ng} / \mathrm{mL})(5,22)$. PRL is secreted episodically, and its levels measured during the day may possibly be beyond the upper limit of normality for a particular laboratory in healthy individuals $(1,3)$. The diagnosis of hyperprolactinemia is made when serum PRL levels are found on two separate occasions to be above the standard upper limit of normal range (usually 20 to 25 $\mathrm{ng} / \mathrm{mL}$ or 400 to $500 \mathrm{mIU} /$ liter $)(4,39)$. Nevertheless, a single determination may be sufficient if PRL levels are clearly elevated (e.g., > $100 \mathrm{ng} / \mathrm{mL}$ ) (6).
The magnitude of PRL elevation can be useful in determining the etiology of hyperprolactinemia, since the highest values are found in patients with prolactinomas (1-5). For example, levels $>250 \mathrm{ng} / \mathrm{mL}$ are highly suggestive of the presence of a macroprolactinoma (3-5), although they may occasionally be found in other conditions (27), as shown below. In contrast, most patients with pseudoprolactinomas, drug-induced hyperprolactinemia or systemic diseases present with PRL levels < $100 \mathrm{ng} / \mathrm{mL}(6,27)$. However, exceptions to theses rules are not rare $(1,3)$.

\section{Pseudoprolactinomas}

In patients with "pseudoprolactinomas", whose main etiology are nonfunctioning pituitary adenomas (NFPA), hyperprolactinemia results from compression of the pi- 
tuitary stalk and PRL levels are generally $<100 \mathrm{ng} /$ $\mathrm{mL}(1,84,85)$, but could rarely exceed $250 \mathrm{ng} / \mathrm{mL}$ $(27,86)$. In the Brazilian Multicenter Study on Hyperprolactinemia (BMSH), among 82 patients with NFPA, PRL levels ranged from 28 to $490 \mathrm{ng} / \mathrm{mL}$ (mean, 80.9 \pm 54.5 ), but in $82 \%$ they were $<100 \mathrm{ng} / \mathrm{mL}$ (Table 4 ) (27). Previously, there have been reports of a NFPA with PRL of $662 \mathrm{ng} / \mathrm{mL}$ and an intrasellar plasmacytoma with suprasellar extension and PRL levels of 504 $\mathrm{ng} / \mathrm{mL}(86,87)$. More recently, very high PRL levels $(1,403 \mathrm{ng} / \mathrm{mL})$ were also reported in a patient with a giant aneurysm of the internal carotid artery (88).

Acromegalic patients may occasionally present very high PRL levels (e.g., > 2,000 ng/mL) in cases of cosecreting GH \& PRL adenomas. These patients may have a dramatic response to cabergoline (Figure 7) (72).

Table 4. Prolactin levels ( $\mathrm{ng} / \mathrm{mL}$ ) according to the etiology of the hyperprolactinemia in the Brazilian multicenter study on hyperprolactinemia

\begin{tabular}{lcc}
\hline Etiology & $\mathbf{n}^{\mathbf{0}}(\%)$ & Mean PRL (range) \\
\hline Macroprolactinomas & $250(20.2)$ & $1422.9 \pm 3134.7(108-21,200)$ \\
Microprolactinomas & $444(36)$ & $165.6 \pm 255.1(32-525)$ \\
Idiopathic & $45(3.6)$ & $163.9 \pm 81.8(46-328)$ \\
Macroprolactinemia & $115(9.3)$ & $119.5 \pm 112.9(32.5-404)$ \\
Drug-induced & $180(14.6)$ & $105.1 \pm 73.2(28-380)$ \\
Acromegaly & $40(3.2)$ & $99.3 \pm 57.4(28-275)$ \\
NFPA & $82(6.6)$ & $80.9 \pm 54.5(28-490)$ \\
Primary hypothyroidism & $78(6.3)$ & $74.6 \pm 42.4(30-253)$ \\
\hline
\end{tabular}

NFPA: non-functioning pituitary adenomas.

Adapted from ref. 27.

\section{Prolactinomas}

Circulating PRL levels usually parallel tumor size, in a way that microprolactinomas (MIC) (diameter $<10 \mathrm{~mm}$ ) usually result in PRL levels of 100-200 ng/mL, but not infrequently they may be $<100 \mathrm{ng} / \mathrm{mL}$, and occasionally reach $500 \mathrm{ng} / \mathrm{mL}$ or more $(6,7)$. Macroprolactinomas (MAC) (diameter $\geq 10 \mathrm{~mm}$ ) are typically associated with PRL values $>250 \mathrm{ng} / \mathrm{mL}$ (4-6), which not seldom may exceed $1,000 \mathrm{ng} / \mathrm{mL}(27)$.

In the BMSH, PRL varied between 32-525 ng/ $\mathrm{mL}$ (mean, $165.6 \pm 255.1 ;<100 \mathrm{ng} / \mathrm{mL}$ in $25 \%, 100$ $249 \mathrm{ng} / \mathrm{mL}$ in $45.8 \%$, and $\geq 250 \mathrm{ng} / \mathrm{mL}$ in $8.2 \%$ ) in MIC whereas in MAC, PRL ranged from 108-21,200 $\mathrm{ng} / \mathrm{mL}$ (mean, $1422.9 \pm 3134.7 ;>250 \mathrm{ng} / \mathrm{mL}$ in $67 \%$ ) (27) (Table 3 ). On the other hand, if a very large macroadenoma (greater than $3 \mathrm{~cm}$ ) is found in a patient with a normal or only mildly elevated PRL level, the socalled "hook effect" must be suspected. The hook effect is an assay artifact caused by an extremely high level of PRL, which saturates the detecting antibody used in the PRL assay, thus resulting in a falsely low reported value $(39,89,90)$. The hook effect may be preventing by repeating the assay after a 1:100 serum sample dilution. Indeed, this step will result in a dramatic rise in PRL levels if the patient has a macroprolactinoma, remaining low in cases of NPFA $(1,6,89)$. In one of such cases, a patient with a giant skull base tumor with suprasellar extension and PRL of $103 \mathrm{ng} / \mathrm{mL}$ underwent debulking surgery through a right frontal
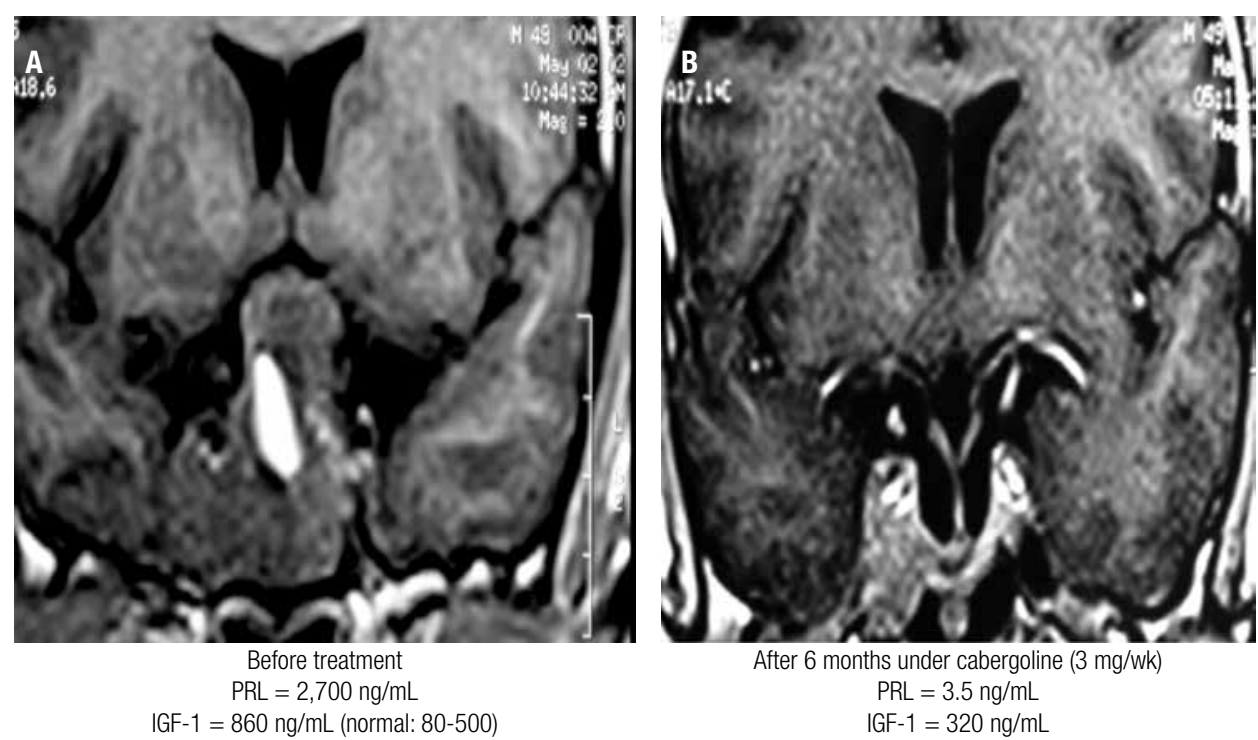

Figure 7. Pituitary MRI from a patient with a GH and prolactin cosecreting adenoma before $(\mathbf{A})$ and after $(\mathbf{B})$ the treatment with cabergoline. PRL level was 2,700 and there was a dramatic response to cabergoline (Adapted from Ref. 72). Acromegaly should be screened in any patient with a pituitary macroadenoma. 
craniotomy approach with the presurgical diagnosis of invasive NFPA. The excised tumor tissue showed a strong positive staining for PRL and after surgery his serum prolactin level was reported as $13,144 \mathrm{ng} / \mathrm{mL}$ (89) (Figure 8). In another case, retesting the original serum prolactin sample of $164.5 \mathrm{ng} / \mathrm{mL}$ (normal, 1.6 to 18.8) with serial dilutions revealed prolactin level of $26,000 \mathrm{ng} / \mathrm{mL}$. This patient also underwent unwarranted surgical debulking procedure $(90)$.

Cystic macroprolactinomas (Figure 9), which have a smaller amount of lactotroph cells, may present with modest increase in PRL levels, and tend to respond less favorably to dopamine agonist therapy (91). Once the possibility of falsely low PRL levels is excluded, any PRL value $<100 \mathrm{ng} / \mathrm{mL}$ in a patient harboring a pituitary macroadenoma is therefore highly suggestive of a pseudoprolactinoma $(3,4,85)$.

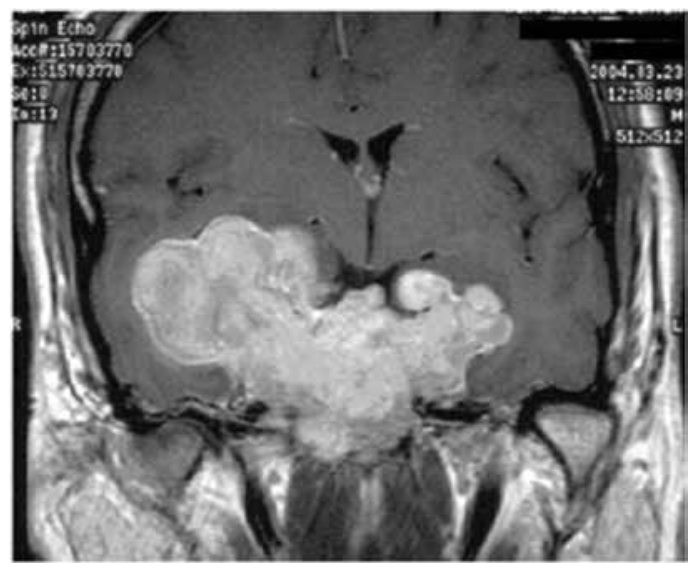

Figure 8. Giant invasive pituitary prolactinoma with falsely low serum PRL (103 $\mathrm{ng} / \mathrm{mL}$.) due to the hook effect. PRL levels rose to $13,144 \mathrm{ng} / \mathrm{mL}$ after a 1:100 serum sample dilution (Adapted from Ref. 89).

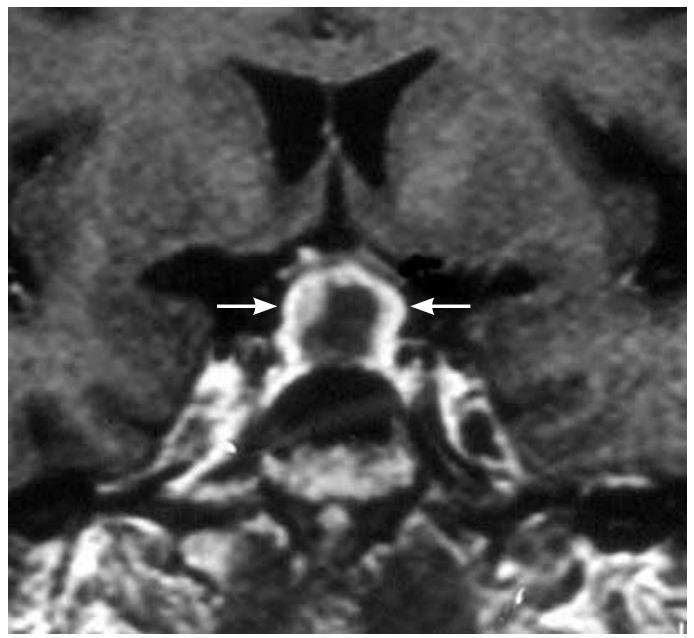

Figure 9. A large cystic macroprolactinoma (arrows). PRL level was 88 $\mathrm{ng} / \mathrm{mL}$ and the treatment with cabergoline did not result in PRL normalization nor in significant tumor shrinkage.

\section{Systemic diseases/Drugs}

In patients with systemic diseases or in use of drugs that induce hyperprolactinemia, PRL levels are usually < $100 \mathrm{ng} / \mathrm{mL}$ (3-5). However, marked hyperprolactinemia (PRL levels as high as $2000 \mathrm{ng} /$ $\mathrm{mL}$ ) can be found in patients with renal failure using medications that could induce hyperprolactinemia (92). In patients with primary hypothyroidism, Honbo and cols. (34) reported a modest PRL increase in 40\% of patients, but levels $>25 \mu \mathrm{g} /$ liter only occurred in $10 \%$ of cases. Another study found hyperprolactinemia in $42 \%$ of hypothyroid subjects, but only in about $30 \%$ PRL levels were $>60 \mu \mathrm{g} /$ liter (93). Among 78 patients with primary hypothyroidism evaluated in $\mathrm{BMSH}, \mathrm{PRL}$ levels range was 30-253 (mean, $74.6 \pm 42.4 ;<100 \mathrm{ng}$ / $\mathrm{mL}$ in $87 \%)(27)$.

Although PRL elevation is usually mild (25-100 $\mathrm{ng} / \mathrm{mL}$ ), in cases of drug-induced hyperprolactinemia, it is also highly variable (26). Indeed, metoclopramide, risperidone, and phenothiazines can lead to prolactin levels > $200 \mathrm{ng} / \mathrm{mL}(4,6,26)$. Among 180 cases enrolled in BMSH, most (64\%) present PRL levels < $100 \mathrm{ng} / \mathrm{mL}$, but in $5 \%$ they exceed $250 \mathrm{ng} / \mathrm{mL}$ (range, 28-380; mean, $105.1 \pm 73.2)(27)$.

\section{Macroprolactinemia}

In most patients with macroprolactinemia, PRL levels are $<100 \mathrm{ng} / \mathrm{mL}$, but they are highly variable: from 20 $663 \mu \mathrm{g} / \mathrm{L}$ (mean, $61 \pm 66 ;<100 \mu \mathrm{g} / \mathrm{L}$ in about $91 \%$ of cases) (58), to $119.5 \pm 112.9$ (range, 32.5-404; < 100 $\mu \mathrm{g} / \mathrm{L}$ in 74\%) among 115 patients in the BMSH (27). PRL levels were lower in macroprolactinemic patients than in those with monomeric hyperprolactinemia, but there was a great overlap between groups $(43,59-61,65)$.

\section{CONCLUSION}

The definition of the etiology of hyperprolactinemia often represents a great challenge to clinicians, and an accurate diagnosis is paramount before treatment. Indeed, dopamine agonists and surgery represent the therapy of choice for prolactinomas and pseudoprolactinomas, respectively $(5-7,79)$. Moreover, the correction of hypothyroidism and withdrawal of the culprit drug could enable PRL normalization (3-5), while macroprolactinemia usually does not require treatment $(17,21,43,59)$.

The PRL levels may be very useful in determining the cause of PRL and values $>200-250 \mathrm{ng} / \mathrm{mL}$ are hi- 
ghly suggestive of prolactinomas. However, they can occasionally be found in medication-induced hyperprolactinemia and in cases of macroprolactinemia, as well as very rarely in patients with pseudoprolactinomas $(4-6,59,86)$. In the Brazilian Muticenter Study on Hyperprolactinemia, only values of $500 \mathrm{ng} / \mathrm{mL}$ or greater showed a clear distinction between prolactinomas and other causes of hyperprolactinemia (27). On the other hand, when faced with patients with a macroadenoma and hyperprolactinemia, one should be aware of the conditions that may lead to falsely low PRL levels, particularly the hook effect or the presence of a tumor with a large cystic component, which implies in smaller amounts of PRL secreting cells (1). Once excluded these conditions, any patient harboring a macroadenoma associated with PRL levels $<100 \mathrm{ng} / \mathrm{mL}$ will have a pseudoprolactinoma until proven otherwise $(1,4,85)$.

The hook effect must be considered in all patients with large pituitary adenomas and PRL levels within the normal range, or only modestly elevated (e.g., $<200$ $\mathrm{ng} / \mathrm{mL}$ ). The confirmation of this assay artifact may prevent incorrect diagnosis and unnecessary surgical intervention in patients with prolactinomas $(6,89,90)$.

Another important challenge is macroprolactinemia, a condition that represents an often-overlooked, underestimated etiology of hyperproalactinemia. Moreover, macroprolactinemic patients cannot be differentiated by their monomeric hyperprolactinemia counterparts in terms of clinical and neuroradiological findings $(16,44)$, nor by PRL levels, unless they are very high (e.g., > $700 \mathrm{ng} / \mathrm{mL})(59,61,65)$. Although there is no consensus yet on the indications for macroprolactinemia screening, there is an increasing number of endocrinologists who consider this approach for all patients without an obvious etiology for the PRL elevation $(9,16,17,21,43-45,60,61,64,94-96)$. Noteworthy, PRL measurement should be avoided in asymptomatic patients in the absence of a known pituitary adenoma to prevent challenges associated with macroprolactinemia.

An algorithm suggested by the authors for evaluation of hyperproplactinemia is shown in figure 10 .

Disclosure: no potential conflict of interest relevant to this article was reported.

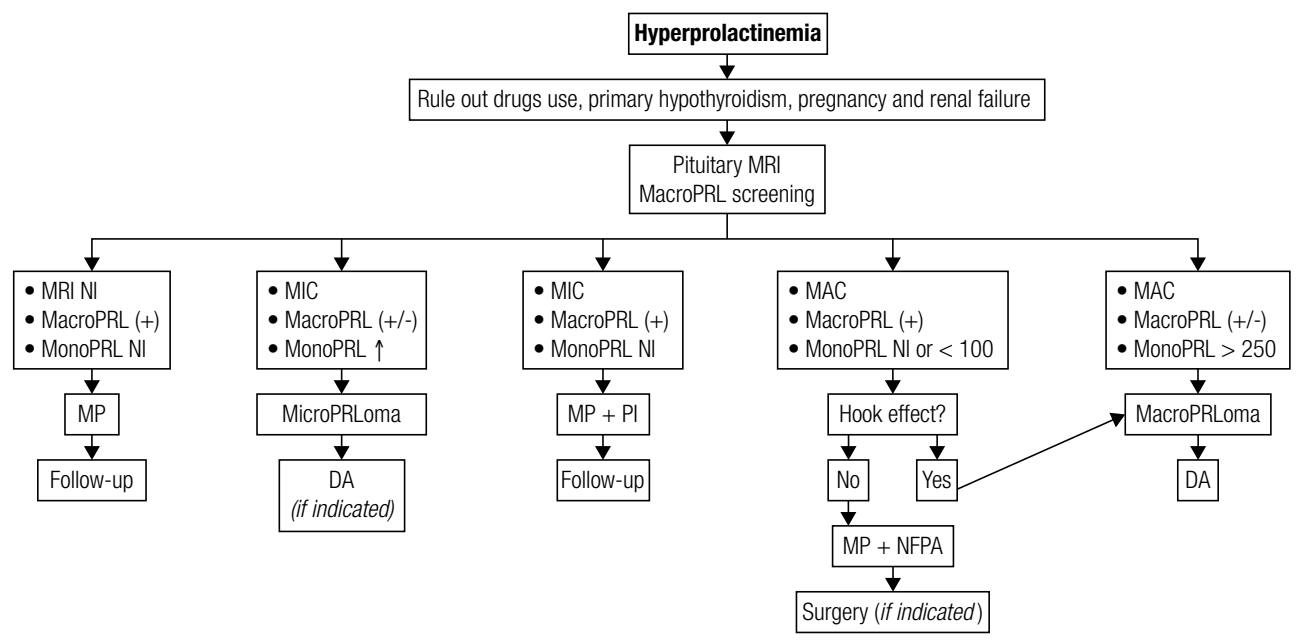

Figure 10. Evaluation of hyperprolactinemia.

NI: normal; MacroPRL: macroprolactin; MIC: microadenoma; MP: macroprolactinemia; MonoPRL: monomeric prolactin; MAC: macroadenoma; MicroPRLoma: microprolactinoma; $\uparrow$ : High; PI: pituitary incidentaloma; MacroPRLoma: macroprolactinoma; NFPA: non-functioning pituitary adenoma; DA: dopamine agonist; +: positive; +/-: positive or negative.

\section{REFERENCES}

1. Vilar L, Naves LA, Gadelha MR. Pitfalls in the diagnosis of hyperprolactinemia. Arq Bras Endocrinol Metab. 2003;47(4):347-57.

2. Biller BM, Luciano A, Crosignani PG, Molitch M, Olive D, Rebar R, et al. Guidelines for the diagnosis and treatment of hyperprolactinemia. J Reprod Med. 1999;44 (suppl 12):1075-84.

3. Molitch ME. Disorders of prolactin secretion. Endocrinol Metab Clin North Am. 2001;30:585-610.

4. Vilar L, Naves LA. Avaliação diagnóstica da hiperprolactinemia. In: Vilar L, et al, editors. Endocrinologia Clínica. 5a ed. Rio de Janeiro: Guanabara Koogan; 2013. p. 39-49.
5. Bronstein MD. Disorders of prolactin secretion and prolactinomas. In: DeGroot LJ, Jameson JL, editors. Endocrinology. 6th ed. Philadelphia: Saunders/Elsevier; 2010. p. 333-57.

6. Melmed S, Casanueva FF, Hoffman AR, Kleinberg DL, Montori VM, Schlechte JA, et al. Diagnosis and treatment of hyperprolactinemia: An Endocrine Society clinical practice guideline. J Clin Endocrinol Metab. 2011;96(2):273-88.

7. Mancini $T$, Casanueva FF, Giustina A. Hyperprolactinemia and prolactinomas. Endocrinol Metab Clin North Am. 2008;37(1):67-99.

8. Josimovich JB, Lavenhar MA, Devanesan MM, Sesta HJ, Wilchins SA, Smith AC. Heterogeneous distribution of serum prolactin va- 
lues in apparently healthy young women, and the effects of oral contraceptive medication. Fertil Steril. 1987;47(5):785-91.

9. Thirunavakkarasu K, Dutta P, Sridhar S, Dhaliwal L, Prashad GR, Gainder S, et al. Macroprolactinemia in hyperprolactinemic infertile women. Endocrine. 2013;44(3):750-5.

10. Buvat J, Lemaire A, Buvat-Herbaut M, Fourlinnie JC, Racadot A, Fossati P. Hyperprolactinemia and sexual function in men. Horm Res. 1985;22(3):196-203.

11. Mah PM, Webster J. Hyperprolactinemia: etiology, diagnosis, and management. Semin Reprod Med. 2002; 20(4):365-74.

12. LaTorre D, Falorni A. Pharmacological causes of hyperprolactinemia. Ther Clin Risk Manag. 2007:3(5) 929-51.

13. Suh HK, Frantz AG. Size heterogeneity of human prolactin in plasma and pituitary extracts. J Clin Endocrinol Metab. 1974;39(5):928-35.

14. SinhaYN. Structural variants of prolactin: occurrence and physiological significance. Endocr Rev. 1995;16(3):354-69.

15. Jackson RD, Wortsman J, Malarkey WB. Characterization of a large molecular weight prolactin in women with idiopathic hyperprolactinemia and normal menses. J Clin Endocrinol Metab. 1985;61(2):258-64.

16. Kasum M, Oreskovic S, Zec I, Jezek D, Tomic V, Gall V, et al. Macroprolactinemia: new insights in hyperprolactinemia. Biochem Med (Zagreb). 2012;22(2):171-9.

17. Shimatsu A, Hattori N. Macroprolactinemia: diagnostic, clinical, and pathogenic significance. Clin Dev Immunol. 2012;2012:167132.

18. Cavaco B, Leite V, Santos MA, Arranhado E, Sobrinho LG. Some forms of big big prolactin behave as a complex of monomeric prolactin with an immunoglobulin $G$ in patients with macroprolactinemia or prolactinoma. J Clin Endocrinol Metab. 1995;80(8):2342-6.

19. Glezer A, Bronstein MD. Approach to the patient with persistent hyperprolactinemia and negative sellar imaging. J Clin Endocrinol Metab. 2012;97(7):2211-6.

20. Glezer A, Soares CR, Vieira JG, Giannella-Neto D, Ribela MT, Goffin $V$, et al. Human macroprolactin displays low biological activity via its homologous receptor in a new sensitive bioassay. J Clin Endocrinol Metab. 2006; 91(3):1048-55.

21. Gibney J, Smith TP, McKenna TJ. The impact on clinical practice of routine screening for macroprolactin. J Clin Endocrinol Metab. 2005; 90(7):3927-32.

22. Gillam MO, Molitch ME. Prolactin. In: Melmed S, editor. Pituitary. 3rd ed. Philadelphia: Elsevier; 2011. p. 119-66.

23. Tarín JJ, Hermenegildo C, García-Pérez MA, Cano A. Endocrinology and physiology of pseudocyesis. Reprod Biol Endocrinol. 2013;11:39.

24. Voicu V, Medvedovici A, Ranetti AE, Rădulescu FŞ. Drug-induced hypo- and hyperprolactinemia: mechanisms, clinical and therapeutic consequences. Expert Opin Drug Metab Toxicol. 2013;9(8):955-68.

25. Soares Leaes CG, Pereira-Lima JF, da Costa Oliveira M. A case of sibutramine-induced hyperprolactinemia. Neuro Endocrinol Lett. 2011;32(5):616-8.

26. Molitch ME. Drugs and prolactin. Pituitary. 2008;11(2):209-18.

27. Vilar L, Freitas MC, Naves LA, Casulari LA, Azevedo M, Montenegro $\mathrm{R} \mathrm{Jr}$, et al. Diagnosis and management of hyperprolactinemia: results of a Brazilian multicenter study with 1234 patients. J Endocrinol Invest. 2008;31(5):436-44.

28. Petit A, Piednoir D, Germain ML, Trenque T. Drug-induced hyperprolactinemia: a case-non-case study from the national pharmacovigilance database. Therapie. 2003;58(2):159-63.

29. Johnsen E, Kroken RA, Abaza M, Olberg H, Jørgensen HA. Antipsychotic-induced hyperprolactinemia: a cross-sectional survey. J Clin Psychopharmacol. 2008;28(6):686-90.

30. Inder WJ, Castle D. Antipsychotic-induced hyperprolactinaemia. Aust N Z J Psychiatry. 2011;45(10):830-7.

31. Kunwar AR, Megna JL. Resolution of risperidone-induced hyperprolactinemia with substitution of quetiapine. Ann Pharmacother. 2003;37(2):206-8.
32. Kamel N, Ilgin SD, Güllü S, Tonyukuk VC, Deda H. Lymphocytic hypophysitis and infundibuloneurohypophysitis; clinical and pathological evaluations. Endocr J. 1999;46(4):505-12.

33. Hekimsoy Z, Kafesçiler S, Güçlü F, Ozmen B. The prevalence of hyperprolactinemia in overt and subclinical hypothyroidism. Endocr J. 2010; 57(12):1011-5.

34. Honbo KS, Herle AJV, Kellett KA. Serum prolactin levels in untreated primary hypothyroidism. Am J Med. 1978;64(5):782-7.

35. StrykerTD, Molitch ME. Reversible hyperthyrotropinemia, hyperthyroxinemia and hyperprolactinemia due to adrenal insufficiency. Am J Med.1985;79(2):271-6.

36. Falaschi P, del Pozo E, Rocco A, Toscano V, Petrangeli E, Pompei P, Frajese G. Prolactin release in polycystic ovary. Obstet Gynecol. 1980; 55(5):579-82.

37. Filho RB, Domingues L, Naves L, Ferraz E, Alves A, Casulari LA. Polycystic ovary syndrome and hyperprolactinemia are distinct entities. Gynecol Endocrinol. 2007; 23(5):267-72.

38. Robin G, Catteau-Jonard S, Young J, Dewailly D. Physiopathological link between polycystic ovary syndrome and hyperprolactinemia: myth or reality? Gynecol Obstet Fertil. 2011;39(3):141-5.

39. Huang W, Molitch M. Evaluation and management of galactorrhea. Am Fam Physician. 2012;85(11):1073-80.

40. Morgan MY, Jakobovits AW, Gore MB, Wills MR, Sherlock S. Serum prolactin in liver disease and its relationship to gynaecomastia. Gut. 1978;19(3):170-4.

41. Nardoni A, Marchetti E, Geatti O, Di Piazza V, Rossi G, Cedaro P. Prolactin in chronic alcoholic liver diseases with and without gynecomastia. Minerva Med. 1985; 76(1-2):37-42.

42. De Bellis A, Colao A, Pivonello R, Savoia A, Battaglia M, Ruocco $\mathrm{G}$, et al. Antipituitary antibodies in idiopathic hyperprolactinemic patients. Ann NY Acad Sci. 2007; 1107:129-35.

43. Donadio F, Barbieri A, Angioni R, Mantovani G, Beck-Peccoz P, Spada A, Lania AG. Patients with macroprolactinaemia: clinical and radiological features. Eur J Clin Invest. 2007;37(7):552-7.

44. Isik S, Berker D, TutuncuYA, Ozuguz U, Gokay F, Erden G, et al. Clinical and radiological findings in macroprolactinemia. Endocrine. 2012;41(2):327-33.

45. Suliman AM, Smith TP, Gibney J, McKenna TJ. Frequent misdiagnosis and mismanagement of hyperprolactinemic patients before the introduction of macroprolactin screening: application of a new strict laboratory definition of macroprolactinemia. Clin Chem. 2003;49(9):1504-9.

46. Modest GA, Fangman JJW. Nipple percing and hyperprolactinemia. N Engl J Med. 2002;347(20):1626-7.

47. DemirtasY, SariguneyY, Cukurluoglu O, Ayhan S, Celebi C. Nipple piercing: it is wiser to avoid in patients with hyperprolactinemia. Dermatol Surg. 2004;30(8):1184.

48. Sun GE, Pantalone KM, Gupta M, Kennedy L, Nasr C, Constantiner $\mathrm{M}$, et al. Is chronic nipple piercing associated with hyperprolactinemia? Pituitary. 2013;16(3):351-3.

49. Stanisic TH, Donovan J. Prolactin secreting renal cell carcinoma. J Urol. 1986;136(1):85-6.

50. Hoffman WH, Gala RR, Kovacs K, Subramanian MG. Ectopic prolactin secretion from a gonadoblastoma. Cancer. 1987;60(11):2690-5.

51. Hsu CT, Yu MH, Lee CY, Jong HL, Yeh MY. Ectopic production of prolactin in uterine cervical carcinoma. Gynecol Oncol. 1992;44(2):166-71.

52. Arbaiza D, Noriega K, Marcial J, Wachtel A, Perez C, Torres CF. Ectopic production of prolactin in an infant with non-Hodgkin lymphoma. Med Pediatr Oncol. 1999;32(4):311-2.

53. Bhatavdekar JM, Patel DD, Chikhlikar PR, Shah NG, Vora HH, Ghosh N, et al. Ectopic production of prolactin by colorectal adenocarcinoma. Dis Colon Rectum. 2001;44(1):119-27.

54. Kallenberg GA, Pesce CM, Norman B, Ratner RE, Silvergerg SG. Ectopic hyperprolactinemia resulting from an ovarian teratoma. JAMA. 1990;263(18):2472-4. 
55. Palmer PE, Bogojavlensky S, Bhan AK, Scully RE. Prolactinoma in wall of ovarian dermoid cyst with hyperprolactinemia. Obstet Gynecol. 1990;75(3 Pt 2):540-3.

56. Elms AF, Carlan SJ, Rich AE, Cerezo L. Ovarian tumor-derived ectopic hyperprolactinemia. Pituitary. 2012;15(4):552-5.

57. Proust-Lemoine E, Mitchell V, Deruelle P, Lamblin A, Néraud B, Leroy $\mathrm{X}$, et al. Ectopic hyperprolactinaemia in a woman with a mesocolic perivascular epithelioid cell tumor ("PEComa"). Ann Endocrinol (Paris). 2008;69(3):240-3.

58. Simsir IY, Kocabas GU, Sahin SB, Erdogan M, Cetinkalp S, Saygili $\mathrm{F}$, et al. A case of an ectopic prolactinoma. Gynecol Endocrinol. 2012;28(2):148-9.

59. Vallette-Kasic S, Morange-Ramos I, Selim A, Gunz G, Morange S, Enjalbert $A$, et al. Macroprolactinemia revisited: a study on 106 patients. J Clin Endocrinol Metab. 2002;87(2):581-8.

60. Strachan MW, Teoh WL, Don-Wauchope AC, Seth J, Stoddart M, Beckett GJ. Clinical and radiological features of patients with macroprolactinaemia. Clin Endocrinol (Oxf). 2003;59(3):339-46.

61. Vilar L, Moura E, Canadas V, Gusmão A, Campos R, Leal E, et al. Prevalence of macroprolactinemia among 115 patients with hyperprolactinemia. Arq Bras Endocrinol Metab. 2007;51(1):86-91.

62. Smith TP, Suliman AM, Fahie-Wilson MN, McKenna TJ. Gross variability in the detection of prolactin in sera containing big big prolactin (macroprolactin) by commercial immunoassays. J Clin Endocrinol Metab. 2002; 87(12):5410-5.

63. Vieira JG, Tachibana TT, Obara LH, Maciel RM. Extensive experience and validation of polyethylene glycol precipitation as a screening method for macroprolactinaemia. Clin Chem. 1988; 44 (8 Pt 1):1758-9.

64. Vieira JGH, TachibanaTT, Ferrer CM, de Sá J, Biscolla RP, Ana Hoff $A O$, et al. Hyperprolactinemia: new assay more specific for the monomeric form does not eliminate screening for macroprolactin with polyethylene glycol precipitation. Arq Bras Endocrinol Metab. 2010;54(9):856-7.

65. Vilar L, Naves LA, Freitas MC, Lima M, Canadas V, Albuquerque $\mathrm{JL}$, et al. Clinical and laboratory features greatly overlap in patients with macroprolactinemia or monomeric hyperprolactinemia. Minerva Endocrinol. 2007;2(2):79-86.

66. Bronstein MD. Editorial: is macroprolactinemia just a diagnostic pitfall? Endocrine. 2012;41(2):169-70.

67. Tamer G, Telci A, Mert M, Uzum AK, Aral F, Tanakol R, et al. Prevalence of pituitary adenomas in macroprolactinemic patients may be higher than it is presumed. Endocrine. 2012;41(1):138-43.

68. Glezer A, D'Alva CB, Salgado LR, Musolino NR, Serafini P, Vieira JG, et al. Pitfalls in pituitary diagnosis: peculiarities of three cases. Clin Endocrinol (Oxf). 2002; 57(1):135-9.

69. Elenkova A, Genov N, Abadzhieva Z, Kirilov G, Vasilev V, Kalinov $\mathrm{K}$, et al. Macroprolactinemia in patients with prolactinomas: prevalence and clinical significance. Exp Clin Endocrinol Diabetes. 2013;121(4):201-5.

70. Hayashida SA, Marcondes JA, Soares JM Jr, Rocha MP, Barcellos $\mathrm{CR}$, Kobayashi NK, et al. Evaluation of macroprolactinemia in 259 women under investigation for polycystic ovary syndrome. Clin Endocrinol (Oxf). 2013 Jun 12. [Epub ahead of print]

71. Guay AT, Sabharwal P, Varma S, Malarkey WB. Delayed diagnosis of psychological erectile dysfunction because of the presence of macroprolactinemia. J Clin Endocrinol Metab. 1996;81(7):2512-4.

72. Vilar L, Czepielewsk MA, Naves LA, Rollin GA, Casulari LA, CoeIho CE. Substantial shrinkage of adenomas cosecreting growth hormone and prolactin with use of cabergoline therapy. Endocr Pract. 2007;13(4):396-402.

73. Teoh SK, Lex BW, Mendelson JH, Mello NK, Cochin J. Hyperprolactinemia and macrocytosis in women with alcohol and polysubstance dependence. J Stud Alcohol. 1992;53(2):176-82.

74. Freitas MC, Lima LHC. Diagnóstico e tratamento do hipotiroidismo. In: Vilar L, et al., eds. Endocrinologia Clínica. 5a ed. Rio de Janeiro: Guanabara Koogan, 2013. p. 297-309.
75. Vance ML, Thorner M. Prolactinoma. Endocrinol Metab Clin North Am. 1987;16:731-54.

76. Kleinberg DL, Noel GL, Frantz AG. Galactorrhea: a study of 235 cases, including 48 with pituitary tumors. N Engl J Med. 1977;296(11):589-600.

77. Freda PU, Post KD. Differential diagnosis of sellar masses. Endocrinol Metab Clin North Am. 1999;28:81-117.

78. Glezer A, Paraiba DB, Bronstein MD. Rare sellar lesions. Endocrinol Metab Clin North Am. 2008;37:195-211.

79. Naidich MJ, Russell EJ. Current approaches to imaging of the sellar region and pituitary. Endocrinol Metab Clin North Am. 1999;28:45-79.

80. Molitch ME. Management of incidentally found nonfunctional pituitary tumors. Neurosurg Clin N Am. 2012;23(4):543-53.

81. Vilar L, Azevedo MF, Barisic G, Naves LA. Pituitary incidentalomas Arq Bras Endocrinol Metabol. 2005;49(5):651-6.

82. Abram M, BrueT, Morange I, Girard N, Guibout M, Jaquet P. Pituitary tumor syndrome and hyperprolactinemia in peripheral hypothyroidism. Ann Endocrinol (Paris). 1992;53(5-6):215-23.

83. Atchison JA, Lee PA, Albright AL. Reversible suprasellar pituitary mass secondary to hypothyroidism. JAMA. 1989;262(22):3175-7.

84. Karavitaki N, Thanabalasingham G, Shore HC, Trifanescu R, Ansorge $\mathrm{O}$, Meston $\mathrm{N}$, et al. Do the limits of serum prolactin in disconnection hyperprolactinaemia need re-definition? A study of 226 patients with histologically verified non-functioning pituitary macroadenoma. Clin Endocrinol (Oxf). 2006;65(4):524-9.

85. Korevaar T, Wass JA, Grossman AB, Karavitaki N. Disconnection hyperprolactinaemia in nonadenomatous sellar/parasellar lesions practically never exceeds $2000 \mathrm{mU} / \mathrm{l}$. Clin Endocrinol (Oxf). 2012;76(4):602-3.

86. Albuquerque FC, Hinton DR, Weiss MH. Excessively high prolactin level in a patient with a nonprolactin-secreting adenoma. $J$ Neurosurg. 1998;89(6):1043-6.

87. Smith MV, Laws Jr ER. Magnetic resonance imaging measurements of pituitary stalk compression and deviation in patients with nonprolactin-secreting intrasellar and parasellar tumors: lack of correlation with serum prolactin levels. Neurosurgery. 1994;34(5):834-9.

88. Duarte FH, Machado MC, Lima JR, Salgado LR. Severe hyperprolactinemia associated with internal carotid artery aneurysm: differential diagnosis between prolactinoma and hypothalamic-pituitary disconnection. Arq Bras Endocrinol Metabol. 2008;52(7):1189-93.

89. Fleseriu M, Lee M, Pineyro MM, Skugor M, Reddy SK, Siraj ES, et al. Giant invasive pituitary prolactinoma with falsely low serum prolactin: the significance of 'hook effect'. J Neurooncol. 2006;79(1):41-3.

90. Frieze TW, Mong DP, Koops MK. "Hook effect" in prolactinomas: case report and review of literature. Endocr Pract. 2002;8(4):296-303.

91. Bahuleyan B, Menon G, Nair S, Rao BR, Easwer HV, Krishna K. Non-surgical management of cystic prolactinomas. J Clin Neurosci. 2009;16(11):1421-4.

92. Hou SH, Grossman S, Molitch ME. Hyperprolactinemia in patients with renal insufficiency and chronic renal failure requiring hemodialysis or chronic ambulatory peritoneal dialysis. Am J Kidney Dis. 1985;6(4):245-9.

93. Notsu K, Ito $Y$, Furuya H, Ohguni S, Kato $Y$. Incidence of hyperprolactinemia in patients with Hashimoto's thyroiditis. Endocr $\mathrm{J}$. 1997;44(1):89-94.

94. Jamaluddin FA, Sthaneshwar P, Hussein Z, Othman N, Chan SP. Importance of screening for macroprolactin in all hyperprolactinaemic sera. Malays J Pathol. 2013 ;35(1):59-63.

95. McKennaTJ. Should macroprolactin be measured in all hyperprolactinaemic sera? Clin Endocrinol (Oxf). 2009;71(4):466-9.

96. Lu CC, Hsieh CJ. The importance of measuring macroprolactin in the differential diagnosis of hyperprolactinemic patients. Kaohsiung J Med Sci. 2012;28(2):94-9. 